\title{
FUNDAMENTAL RIGHTS AT THE CROSSROADS OF EU CONSTITUTIONALISM. DECODING THE MEMBER STATES' KEY(S) TO THE CHARTER
}

\author{
SOPHIE PEREZ FERNANDES ${ }^{1}$ \\ University of Minho \\ sophiep@direito.uminho.pt
}

Cómo citar/Citation

Perez Fernandes, S. (2018).

Fundamental rights at the crossroads of EU constitutionalism.

Decoding the Member States' key(s) to the Charter.

Revista de Derecho Comunitario Europeo, 60, 677-715.

doi: https://doi.org/10.18042/cepc/rdce.60.06

\begin{abstract}
The internormative, comprehensive and constantly evolving system of fundamental rights protection progressively built within the European Union legal system and now coded in the Charter of Fundamental Rights of the European Union (CFREU) lies on a balance between the structure and the objectives of the European integration process and the protection of fundamental rights. After retracing some notable steps in order to demonstrate how the protection of fundamental rights has been sedimented at the heart of EU constitutional crossroads, the present text attempts to systematize the coordinates of the application of the CFREU to the Member States on the basis of the relevant ECJ case-law regarding art. 51(1) CFREU. The proposal will provide the frame of reference for the analysis of the Taricco saga as the most recent example of the intricate complexity of building the aforementioned delicate and crucial balance.
\end{abstract}

1 Visiting Assistant Professor at the School of Law of the University of Minho, Portugal. 


\section{Keywords}

EU constitutionalism; fundamental rights; scope of application of the CFREU; standards of protection; primacy, unity and effectiveness of EU law.

\section{LOS DERECHOS FUNDAMENTALES EN LA ENCRUCIJADA DEL CONSTITUCIONALISMO DE LA UE. DESCIFRANDO LA(S) CLAVE(S) DE LA CARTA PARA LOS ESTADOS MIEMBROS}

\section{Resumen}

El sistema internormativo, comprehensivo y en constante evolución de protección de los derechos fundamentales, progresivamente construido dentro del sistema jurídico de la Unión Europea, y ahora codificado en el Carta de los Derechos Fundamentales de la Unión Europea (CDFUE), se asienta sobre un equilibrio entre la estructura y los objetivos del proceso de integración europea y la protección de los derechos fundamentales. Tras repasar algunos de sus más importantes pasos para demostrar cómo la protección de los derechos fundamentales se ha sedimentado en el corazón de la encrucijada constitucional de la Unión, el presente texto intenta sistematizar las coordenadas para la aplicación de la CDFUE a los Estados miembros con la base en la jurisprudencia del Tribunal de Justicia, sobre el art. 51.1 CDFUE. La propuesta formulada proporcionará el marco de referencia para el análisis de la saga Taricco como el ejemplo más reciente de la intrincada complejidad de construir el delicado y crucial equilibrio mencionado.

\section{Palabras clave}

Constitucionalismo de la Unión Europea; derechos fundamentales; ámbito de aplicación de la CDFUE; estándares de protección; primacía, unidad y efectividad del derecho de la Unión Europea.

\section{LES DROITS FONDAMENTAUX À LA CROISÉE DU CONSTITUTIONNALISME DE L'UE. DÉCODANT LA(LES) CLÉ(S) DE LA CHARTE POUR LES ÉTATS MEMBRES}

\section{Résumé}

Le système internormatif, compréhensif et en constante évolution de protection des droits fondamentaux progressivement construit au sein du le système juridique de l'Union européenne et désormais codifié dans la Charte des droits fondamentaux de l'Union européenne (CDFUE) s'appuie sur un équilibre entre la structure et les objectifs du processus d'intégration européenne et la protection des droits fondamentaux. 
Après avoir retracé certaines des étapes les plus importantes pour montrer comment la protection des droits fondamentaux s'est inscrite dans le cœur des carrefours constitutionnels de l'Union, ce texte tente de systématiser les coordonnées pour l'application de la CDFUE aux États membres ayant pour base la jurisprudence de la Cour de justice sur l'art. 51, paragraphe 1, CDFUE. La proposition formulée fournira le cadre d'analyse de la saga Taricco en tant qu'exemple le plus récent de la complexité que revêt la construction de l'équilibre délicat et crucial susmentionné.

\section{Mots clés}

Constitutionalisme de l'UE; droits fondamentaux; champ d'application de la CDFUE; standards de protection; primauté, unité et efficacité du droit de l'UE. 


\section{SUMARIO}

I. INTRODUCTION. II. THE PROGRESSIVE SETTLEMENT OF THE EU SYSTEM OF FUNDAMENTAL RIGTHS PROTECTION AS AN EXPRESSION OF THE EMERGING EU CONSTITUTIONALISM. III. THE CHARTER AS AN ATTEMPT TO HANDLE THE EMERGING EU CONSTITUTIONALISM: 1. From what the Charter states to what the Court in it deciphers regarding Member States compliance. 2. The hardships of setting rules. Decoding the Member States' key(s) to the Charter: a proposal. IV. THE TARICCO SAGA AS A CASE STUDY: 1. Taricco I. A brief overview. 2. Taricco II. A critical analysis. V. CONCLUDING REMARKS. BIBLIOGRAPHY.

\section{INTRODUCTION}

When presented with a binding Charter of Fundamental Rights of the European Union (CFREU), the European Court of Justice (ECJ) was not only presented with the rules governing its application. The ECJ was almost immediately confronted with some of the limits of the system of fundamental rights protection of the European Union (EU) in which the CFREU is but an (pivotal) integral part. And so, the ECJ was called, not just to reflect, but to decide on those defining moments when the CFREU is out of reach or for which the CFREU it not enough or is not alone.

From an evolutionary point of view, the CFREU is both the point of arrival and the starting point of the EU system of fundamental rights protection. As the most recent legal basis of the EU acquis in the field of fundamental rights, the CFREU reaffirms in a single catalog the civil, political, economic and social rights of EU citizens, of persons residing (including legal persons based) within EU territory or somehow affected by activities of its institutions, bodies, offices or agencies ${ }^{2}$. The "visibility exercise" (De Búrca, 2001: 130) carried out through the CFREU underlines the importance and the function of fundamental rights in the EU legal system: an objective function, providing a standard of control (review) of the activities of the authorities responsible for exercising public power in the EU (Lenaerts and Gutiérrez-Fons, 2014: 1575-1576), and a subjective function, as a source of

2 See Preamble of the CFREU, para. 5; see also European Commission (2009: 7). 
protection of the rights of individuals whose situation falls within the scope of application of EU law. In addition to consolidating the EU acquis in the field of fundamental rights in a comprehensive catalog of fundamental rights protected by EU law, the CFREU dictates or at least seeks to outline the modus operandi of the dynamic and internormative EU system of fundamental rights protection. This enlightening intent of the CFREU is particularly evidenced, since its original version, in the provisions of its Title VII, as well as in its accompanying Explanations. With them, the CFREU seeks to outline the coordinates enabling a constructive dialogue involving the legal orders of the EU, the Member States and the European Convention for the Protection of Human Rights and Fundamental Freedoms (ECHR), and their respective institutions (especially judicial ones), in solving fundamental rights problemsan internormative and interinstitutional dialogue that nevertheless ought to preserve the constitutional autonomy of each legal order that integrates the whole.

The mission is as crucial as this balance is delicate.

As the tenth anniversary of the signing of the Treaty of Lisbon approaches, the entry into force of which entailed the recognition of legal binding force for the CFREU [art. 6 (1) TEU], the application of the latter continues to raise more questions than to offer answers. Despite the enlightening intent mentioned above, some of the final provisions of the CFREU raise more doubts than they do anchor certainties regarding the scope of protection of fundamental rights under the CFREU. And such difficulties do not afflict only legal theorists, but also (and especially) legal practitioners ${ }^{3}$.

After briefly retracing some notable steps in order to demonstrate how the protection of fundamental rights has been sedimented at the heart of EU constitutional crossroads ${ }^{4}$, the present text attempts to systematize the coordinates of the application of the CFREU to the Member States on the basis of the relevant ECJ case-law regarding art. 51(1) CFREU. The systematization proposed relies on a triple constellation scenario. This proposal will then provide the frame of reference for the analysis of the Taricco saga as the most recent example of the intricate complexity of building the balance between the structure and the objectives of the European integration process and the protection of fundamental rights.

3 Such is the case of determining the highest level of protection for the purposes of art. 53 CFREU as national/local agents (officials, police) may not have the information required to proceed in accordance with said provision and its interpretation in case-law, or not even be aware of its existence (Freixes, 2012: 125-126).

4 By reference to García de Enterría and Alonso García (2002). 


\section{THE PROGRESSIVE SETTLEMENT OF THE EU SYSTEM OF FUNDAMENTAL RIGTHS PROTECTION AS AN EXPRESSION OF THE EMERGING EU CONSTITUTIONALISM}

Today, respect for fundamental rights is both a founding value (arts. 2 and $49 \mathrm{TEU}$ ) and a structuring principle (art. $6 \mathrm{TEU}$ and art. $51 \mathrm{CFREU}$ ) of the constitutional architecture of the EU. As a principle, both the EU and the Member States must respect fundamental rights as an intrinsic requirement of the EU legal system: the acts of the institutions, bodies, offices and agencies of the EU, as well as the acts of the authorities of the Member States (within the scope of application of EU law), must be in accordance with fundamental rights as protected by EU law.

The evolutionary process that has led to the current status quo met several incidents, moments of uncertainty, many advances and some setbacks, in a history that has extensive records in legal literatures. It is not our purpose here to renew such noble exercise. For the current purposes, suffice is to state that the protection of fundamental rights has been sedimented at the heart of EU constitutional crossroads. The protection of fundamental rights within the EU legal order is perhaps the most paradigmatic, albeit still in progress, example of the interdependence and relative autonomy of the constitutional orders involved (Besselink, 2012: 1), that of the EU and those of the Member States. And so it is because the EU system of fundamental rigths protection is a special expression of a phenomenon of reflexive interaction or cross-fertilization of constitutional norms that coexist in the same political space, being a product of the constitutionalism emerging from the European integration process-and that has found in the concepts of multilevel (Pernice, 1999; Pernice, 2002), composite (Besselink, 2007) or plural (Poiares Maduro, 2006) constitutionalism or interconstitutionality (Lucas Pires, 1997; Rangel, 2009; Gomes Canotilho, 2006; Silveira, 2011a) ${ }^{6}$ several proposals for theorization.

After a relatively short initial period of "valued agnosticism" (Duarte, 2006: 38) (mitigated by some soft-law attempts ${ }^{7}$ ), the ECJ assumed for itself the (leading role in the) protection of fundamental rights in the legal order

5 See, for example, Duarte (2006: 34-52).

6 This theory has been mainly developed in Portuguese legal literature, but the preference for the concept "interconstitutionality" is also shared by some non-Portuguese authors for better expressing the absence of hierarchical relations or top-down impositions in the EU constitutional discourse (Besselink, 2013: 236-237).

7 See, for example, the Declaration on European Identity, Copenhagen, 14 December 1973, para. 1, and the European Parliament (1989: 51-57). 
under construction. The ECJ was first confronted with the alleged infringement of fundamental rights (as guaranteed by national constitutional law) by decisions adopted by Community institutions in the Stork case, but did not examine the ground of complaint which maintained that, when it adopted its decision, the High Authority of the ECSC infringed principles of German constitutional $\mathrm{law}^{8}$. The main reason for this first line of case-law lies in the need to confirm, in an early stage of construction of the Community legal order, its autonomy vis-à-vis the legal orders of the Member States and the primacy of its rules in relation to the rules of national law, including those of a constitutional nature-dimensions proclaimed in the emblematic judgments in Van Gend \& Loos" and Costa/ENEL ${ }^{10}$. The irony is worth registering: "an early, almost primitive, form of constitutional assertion was the denial of fundamental constitutional values" (Tridimas, 2006: 301).

The case-law changed course in the famous Stauder judgment in which the ECJ examined the validity of a Commission decision in the light of "fundamental human rights enshrined in the general principles of Community law and protected by the Court"11. This generic clause set out in Stauder was shortly afterwards complemented in the equally famous judgments in Internationale Handelsgesellschaft, Nold II and Rutili, cases in which the ECJ sought inspiration from the "constitutional traditions common to the Member States"12 and guidelines from "international treaties for the protection of human rights on which the Member States have collaborated or of which they are signatories" 13 , such as the ECHR ${ }^{14}$ that is "of particular significance in that regard"15.

This case-law structures a system for the protection of fundamental rights based on a plurality of sources which still coexist today alongside the CFREU — a system of fundamental rights protection developed in the "space

8 Judgment of the Court in Stork, 1/58, EU:C:1959:4, para. 4; see also judgments of the Court in Nold I, 18/57, EU:C:1959:6, and in Comptoirs de vente du charbon de la Ruhr, 36 to 38/59 and 40/59, EU:C:1960:36.

9 Judgment of the Court in Van Gend \& Loos, 26/62, EU:C:1963:1.

10 Judgment of the Court in Costa/ENEL, 6/64, EU:C:1964:66. See Judgment of the Court in Internationale Handelsgesellschaft, 11/70, EU:C:1970:114, para. 3.

11 Judgment of the Court in Stauder, 29-69, EU:C:1969:57, para. 7.

12 See Judgment of the Court in Internationale Handelsgesellschaft, 11/70, EU:C: 1970:114, para. 4.

13 Judgment of the Court in Nold II, 4/73, EU:C:1974:51, para. 13.

14 First mentioned in the judgment of the Court in Rutili, 36/75, EU:C:1975:137, para. 32.

15 Judgment of the Court in Hoechst, 46/87 and 227/88, EU:C:1989:337, para. 13. 
of internormativity" of the EU (Duarte, 2006: 22). The expression "internormativity" presupposes legal/normative pluralism and seeks to explain the complex phenomena of overlap, cooperation and tension between legal systems that coexist in the same legal and political space, that of the EU, while seeking to articulate solutions that take advantage of this legal pluralism in dealing with matters that affect all involved, without destroying or blocking each other. In particular, an internormative approach to fundamental rights protection within the EU promotes a legal methodology that is friendly to the discursive interaction of different legal orders, favoring solutions of pacification of tensions in an integrative approach of intercomplementarity rather than a hierarchical approach to conflict. Ultimately, an internormative approach to fundamental rights may serve as the basis for the emergence of a principle of primacy of fundamental rights as a decisive principle when the various internormativites that form an integral part of the systemic whole are at a crossroads (Gomes Canotilho, 2010: 180).

In this context, the CFREU does not replace the system of fundamental rights protection in the EU legal order, but rather complements it: first, because the CFREU adds to the sources of fundamental rights protection that were already an integral part of the EU system of fundamental rights protection; and also because the CFREU enshrines a broad catalog of fundamental rights (Braibant, 2001: 47; Ladenburger, 2012: 4). Thus, the CFREU does not change the logic of internormativity in the field of fundamental rights on which the EU system of protection was founded and under which it has developed. It is not only the product of this scenario, but also seeks to promote it. The CFREU is in itself an exercise of internormativity in the field of fundamental rights as the result of the interaction of various sources of fundamental rights protection ${ }^{16}$. And so, the CFREU is well aware that, within the EU legal system, there are sources of fundamental rights protection of a different origin. The CFREU does not seek to harmonize these systems of protection of fundamental rights (Von Danwitz and Paraschas, 2012: 1400-1401), but rather seeks to frame that coexistence in order to settle a certain sense of intersystemic unity and

16 Such an exercise was enshrined in the Cologne mandate (European Council, 1999: 2) and then reflected in the Preamble of the CFREU (para. 5) and in its provisions, which is made particularly clear in the accompanying Explanations (OJ C 303, 14.12.2007, pp. 17-35). The Explanations refer to the ECHR and other international instruments for the protection of human rights, to the constitutional traditions common to the Member States, to provisions of primary and secondary EU law, and to case-law of both the ECJ and the ECtHR. To that extent, the Explanations demonstrate how choices were made based on the intrinsic value of the rights enshrined rather than on the hierarchy of the provisions that enshrine them (Dutheil de la Rochère, 2010: 267). 
coherence ${ }^{17}$, particularly through the interpretative rules set forth in art. 52 and by enshrining the principle of the highest level of protection in art. 53 .

Thus, while the CFREU certinly gives visibility and centrality to fundamental rights within the EU legal order, it leaves the EU system of fundamental rights protection essentially unchanged (Duarte, 2010: 112-115; Iglesias Sánchez, 2012: 1568-1573; Hofmann and Mihaescu, 2013: 82): the CFREU has not turned fundamental rights into a fundamental policy of the EU (Poiares Maduro, 2006: 327) and the system of fundamental rights protection remains the one that results from the three pillars designed in art. 6 TEU (Freixes, 2012: 117-118), including (i) sources of EU origin, to which the CFREU is added, (ii) sources of national origin (the constitutional traditions common to the Member States ${ }^{18}$ ) and (iii) sources of international origin, especially the ECHR (Silveira, 2011b: 80-81).

Whether through the ECJ case-law or in the political and constitutional process leading to the drafting, the proclamation and the entry into force of the CFREU, the EU has adopted an "objective approach" to fundamental rights, not defining them ab initio, rather recognising rights which "pre-exist in the European landscape" (Dutheil de la Rochère, 2010: 265). Still, this "structured network" for the protection of fundamental rights remains subject to a careful filtering "within the framework of the structure and objectives of the EU" in order to guarantee the autonomy of the EU legal order with regard to the legal orders of the Member States and in relation to international law ${ }^{19}$. This "compromise solution" (Lenaerts and Gutiérrez-Fons, 2014: 1559) inscribes fundamental rights protection in an "ideological continuity" (Tridimas, 2006: 302) between the Union and the Member States while at the same time seeking to forge and guarantee the constitutional autonomy of the legal orders involved.

When the EU called for itself the protection of fundamental rights, it sought to provide added value for the protection of fundamental rights, and not to pose a threat to pre-existing protection regimes, especially those of the

17 Regarding the interpretative rule set forth in art. 52(3) CFREU, see the Explanations relating to art. $52 \mathrm{CFREU}$, and, in case-law, the judgments of the Court in JN, C-601/15 PPU, EU:C:2016:84, para. 47, and in JZ, C-294/16 PPU, EU:C: 2016:610, para. 50 .

18 Those do not need "correspond to a conception shared by all Member States as regards the precise way in which the fundamental right or legitimate interest in question is to be protected"-judgment of the Court in Omega, C-36/02, EU:C:2004:614, para. 37.

19 Taking advantage of the words of the Opinion of the Court 2/13 (Accession of the EU to the ECHR), EU:C:2014:2454, para. 167 and 170. 
Member States. But if the protection of fundamental rights forged by the $\mathrm{EU}$ is prima facie an exercise of internormativity in the field of fundamental rights, it was from the outset developed alongside the existential affirmation of the EU legal order's autonomy. This explains how the preservation of the constitutional autonomy of each of the legal orders that integrate the whole, that of the EU and those of the Member States, disquiets the rules of the game in the field of fundamental rights protection. Therefore, rather than operating in terms of peaceful coexistence, both the theory and the practice of fundamental rights should privilege a logic of reflexive interaction of legal provisions that coexist in the same legal and political space, that of the EU. Prioritizing a logic of production of capacities/legitimacies of decision and action in the field of fundamental rights based on the intertwining of the various legal orders that integrate the systemic whole is the method emerging from EU constitutionalism, intrinsically plural but inclusive.

Such entanglement is not without its moments of tension. The different systems that integrate the systemic whole may, in fact, frame the protection of fundamental rights with differences regarding some of their elements-scope of application, content, conditions of exercise, limits, guarantees. Thus, although "the core of the rules" might seem identical, different systems of fundamental rights protection may, or even tend to produce different standards of protection (Egger, 2006: 546). The special value, if not the force, of the system of fundamental rights protection internormatively designed within the EU framework will likely lie in its ability to turn these moments of tension into moments of protection, that is, to provide solutions for the benefit of the individuals interested in the protection of their fundamental rights. This seems to be the design implicitly proclaimed in the Preamble of the CFREU. In so far as the EU, by establishing the citizenship of the Union and by creating an area of freedom, security and justice, places "the individual at the heart of its activities", the method emerging from EU constitutionalism must, in the field of fundamental rights protection, be based on a pro individual logic.

\section{THE CHARTER AS AN ATTEMPT TO HANDLE THE EMERGING EU CONSTITUTIONALISM}

\section{FROM WHAT THE CHARTER STATES TO WHAT THE COURT IN IT DECIPHERS REGARDING MEMBER STATES COMPLIANCE}

The scope of application of fundamental rights as protected by EU law is one of the most important questions in determining the role of fundamental rights in the process of European integration and in shaping the constitutional 
model that supports it. Among the general provisions enshrined in Title VII of the CFREU, that of art. 51(1) has drawn particular attention from caselaw and legal literature. It is, perhaps, the provision that best reflects both the paradoxical and the crucial dimensions of the CFREU, especially as regards its observance by the Member States. As already noted (Eeckhout, 2002: 952958), the CFREU limits its scope of application to the institutions, bodies, offices and agencies of the EU and to the Member States "only when they are implementing Union law", thus resulting in an extensive catalog of fundamental rights with a limited scope of application. Such limitation raises issues of fundamental importance for the future of fundamental rights protection within the EU legal system. And so it is because the question of the scope of application of the CFREU is the "question préalable" (Sarmiento, 2013: 1272) for all other questions concerning protection of fundamental rights within the EU legal system, from the allocation of competences between the EU and the Member States in this field to the delimitation of the jurisdiction of both the ECJ and national courts, in particular supreme and constitutional courts, as well as the interaction of different sources of fundamental rights protection and the determination of the level of protection to be guaranteed in each case.

The drafting of the final provisions of the CFREU, and in particular of art. 51, proved to be particularly difficult (Braibant, 2001: 295). As regards the scope of application of the CFREU, its extension to the Member States was obvious, since they are at the forefront in the application of EU law. The question was to properly frame the scope of such an extension. The apparent simplicity of the formula finally embodied in art. 51(1) CFREU ${ }^{20}$ conceals the real complexity of the equation underlying it - and the variable geometry that, in truth, governs the application of the CFREU ${ }^{21}$ in tandem with the

20 The process leading to the current drafting of art. 51 CFREU shows the preference for restrictive formulations of the scope of application of the CFREU as regards the Member States (De Búrca, 2001: 136-137; Eeckhout, 2002: 954-958; Kaila, 2012: 294-298; Von Danwitz and Paraschas, 2012: 1402-1404).

21 The text is limited to the analysis of art. 51(1) CFREU in so far as it relates to the application of the CFREU to Member States, and its interpretation in ECJ case-law. Thus, it refers to the general scope of application of the CFREU. Indeed, the scope of application of some provisions of the CFREU (such as art. 41) is narrower than the provision of art. 51(1) CFREU, in so far as it is limited to the activities of EU institutions, bodies, offices or agencies, excluding Member States even when they are implementing EU law within the meaning of art. 51(1) CFREU. Also, the opt-out clauses regarding the (non) application of the CFREU to Poland, the United Kingdom and the Czech Republic are not addressed (see Protocol n. 30 annexed to the Treaties and Declaration n. ${ }^{\circ} 53$ annexed to the Final Act of the Intergovernmental Conference, OJ 
differentiated integration approach accommodating the European integration's heterogeneous dynamics (Bellamy and Kröger, 2017: 625-639). In case-law, although some indications had already been left in previous judgments and orders of the ECJ, it was not until 2013, with the soon emblematic Fransson and Melloni judgments ${ }^{22}$, that the coordinates followed by the ECJ regarding the application of the CFREU to the Member States began to be outlined.

First, the case-law established in those judgments confirms that the CFREU is not an instrument for the protection of fundamental rights which is autonomous in nature or of general application-nor has it ever intended to be so. Both in its initial account on the respect by Member States for fundamental rights as guaranteed by the CFREU ${ }^{23}$, and then on how it applies the approach adopted to the specific legal and factual framework in question $^{24}$, the ECJ assimilates in Fransson the concept of "application of EU law" to that of "scope of application of EU law" for the purposes of art. 51(1) CFREU, thus consistently matching the scope of application of the CFREU with the scope of application of EU law. The ECJ has chosen to maintain the status quo (Ritleng, 2013: 272-273): the ECJ interprets art. 51(1) CFREU in a way which gives continuity, which "confirms", its previous case-law relating "to the extent to which actions of the Member States must comply with the requirements flowing from the fundamental rights guaranteed in the legal order of the European Union" 25 , refusing, at least in general, to recognise to the CFREU a more limited scope of application than EU law.

This also implies, first and foremost, that the CFREU is only binding on the Member States through EU law. The same is to say that the CFREU is a consequence of the applicability of EU law in a particular case, but it is not its cause- the CFREU does not itself determine the applicability of EU law. Because most times a picture is worth a thousand words, some scholars have embraced a rather imaged language in this regard. Taking advantage of such language then, in so far as it relates to the application of the CFREU to

C 306, 17.12.2007, pp. 156-157 and 267-268). Additionally, albeit not mentioned in the text, under art. 51(1) CFREU, the CFREU is addressed to the EU institutions, bodies, offices or agencies whether or not they act within the EU legal framework, as confirmed in the judgment of the Court in Ledra Advertising, C-8/15 P to C-10/15 P, EU:C:2016:701, para. 67.

22 Judgments of the Court in Fransson, C-617/10, EU:C:2013:105, and in Melloni, C-399/11, EU:C:2013:107.

23 Judgment of the Court in Fransson, C-617/10, EU:C:2013:105, para. 17-23.

24 Judgment of the Court in Fransson, C-617/10, EU:C:2013:105, para 24-31.

25 Judgment of the Court in Fransson, C-617/10, EU:C:2013:105, para. 18. 
Member States, art. 51(1) CFREU indeed transforms the CFREU into the "shadow" of EU law (Lenaerts and Gutiérrez-Fons, 2014: 1568) and "a shadow cannot cast its own shadow" 26 .

The CFREU does not create "free-standing fundamental rights" (Lenaerts and Gutiérrez-Fons, 2014: 1592) that would replace national constitutional systems for the protection of fundamental rights. The purpose is to safeguard the "constitutional structure of the EU" as reflected in the principle of conferral of powers ${ }^{27}$. This is confirmed by the second part of art. 51(1) CFREU, as well as in its second paragraph, which, together with art. 6(1), second paragraph, TEU, enshrine a "principle of non-expansion of EU competences through the Charter" (Ladenburger, 2012: 17). Limiting the scope of application of the CFREU to the Member States "only when they are implementing Union law" is therefore intended to leave the vertical allocation of competences between the EU and the Member States undisturbed and, thus, respecting the principle of conferral of powers [arts. 4(1) and 5(1)(2) TEU]. In other words, the CFREU does not confer powers on the EU but only limits the exercise of powers conferred. And since the CFREU does not create nor does it modify the powers of the EU, none of its provisions can be invoked to serve as a basis for conferring competence on the $\mathrm{EU}^{28}$ — and, in particular, to serve as a basis for the jurisdiction of the ECJ in relation to a situation not falling within the scope of application of $\mathrm{EU} \mathrm{law}^{29}$.

On the basis of the principle of conferral of powers, consideration of the powers conferred on the EU is the starting point (Silveira, 2014: 183) for assessing the applicability of EU law and thus of the CFREU in a specific case. It is, however, a starting point in so far as, on the one hand, there is no exact correlation between "the extent of the Union's legislative competence and its capacity of affecting fundamental rights" (Ladenburger, 2012: 21) and that, on the other hand, "the mere fact that a national measure comes within an area in which the European Union has powers cannot bring it within the scope of EU law, and, therefore, cannot render the Charter applicable" ${ }^{30}$. It is, indeed, necessary that the interpretation or application of "a rule of Union law other

26 Opinion of Advocate General M. Bobek in Ispas, C-298/16, EU:C:2017:650, para. 30.

27 Opinion of the Court 2/13 (Accession of the EU to the ECHR), EU:C:2014:2454, para. 165 and 171.

28 Judgment of the Court in Dereci, C-256/11, EU:C:2011:734, para. 69-72.

29 Judgment of the Court in Fransson, C-617/10, EU:C:2013:105, para. 22.

30 Judgment of the Court in Julian Hernández, C-198/13, EU:C:2014:2055, para. 36. 
than those set out in the Charter" ${ }^{31}$ be concerned in the case at hand, a rule of EU law that would trigger the application of the CFREU, which would act as a "catalyst for the application of the Charter by Member States" (Sarmiento, 2013: 1279-1287) ${ }^{32}$. It might be a rule or a principle of EU law, of primary or secondary law or of jurisprudential origin, whether clearly identified (for example, a provision in a regulation or a directive) or identified by way of interpretation. But, as the Siragusa judgment clarified, it must be concluded, in the light of the entire relevant legal and factual background, that there is a sufficient link between the situation in question and EU law, a connection which is not merely incidental, indirect, or hypothetical ${ }^{33}$.

Additionally, the case-law established in Fransson and Melloni also highlights the centrality of the CFREU in situations falling within the scope of application of EU law. The CFREU operates as an instrument for the protection of fundamental rights which is automatically applicable within the scope of application of EU law since "[the] applicability of European Union law entails applicability of the fundamental rights guaranteed by the Charter" ${ }^{34}$. Taking advantage of the expedient formula of Advocate General Sharpston, "if EU law applies, the Charter applies." 35 The ECJ excludes, at least as a general rule, the possibility for Member States to act within the scope of application of EU

31 See, inter alia, orders of the Court in Pedone, C-498/12, EU:C:2013:76, para. 14; in Gentile, C-499/12, EU:C:2013:77, para. 14; in Loreti, C-555/12, EU:C:2013:174, para. 17; in T., C-73/13, EU:C:2013:299, para. 13; in S. Paio, C-258/13, EU:C: 2013:810, para. 21; in Dutka, C-614/12 and C-10/13, EU:C:2014:30, para. 14; and the judgment in Torralbo Marcos, C-265/13, EU:C:2014:187, para. 33.

32 The Author refers to three types of "triggering rules" - i) "mandating rules" which contain a "clear obligation, as to the goals and/or the means addressed to the Member States" (giving as an example the underlying situation in Fransson); (ii) "optioning rules" which recognise a certain margin of appreciation to the Member States (giving as an example the underlying situation in the judgment of the Court in N.S., C-411/10 and C-493/10, EU:C:2011:865); and (iii) "remedial rules" regarding EU-made remedies developed through the ECJ case-law on the basis of the principle of loyal cooperation, including access to justice, procedural guarantees, interim measures, and damages action (giving as an example the underlying situation in the judgment of the Court in DEB, C-279/09, EU:C:2010:811)—complemented by "exclusionary rules", to be interpreted restrictively as they exclude certain areas of Member State action from the scope of application of a EU legal act.

33 Judgment of the Court in Siragusa, C-206/13, EU:C:2014:126, para. 24.

34 Judgment of the Court in Fransson, C-617/10, EU:C:2013:105, para. 21.

35 Opinion of Advocate General E. Sharpston in YS, C-141/12 and C-372/12, EU:C: 2013:838, para. 86 . 
law without being bound by the CFREU. That is so because, by virtue of the principle of the Union based on the rule of law, "neither its Member States nor its institutions can avoid a review of the question whether the measures adopted by them are in conformity with the basic constitutional charter"36 on which the EU is based, the CFREU included by virtue of art. 6(1) TEU. Thus, in a situation falling within the scope of application of EU law, the relevant standard of fundamental rights protection will be the one determined by virtue of the provisions set out in the CFREU, including as regards the determination of the highest level of protection under art. 53 CFREU.

Furthermore, both the interpretation given to the concept of "application of EU law" within the meaning of art. 51(1) CFREU and its combined reading with the provision of art. 53 CFREU as interpreted by the ECJ reveals how apparent the simplicity of the legal formula "only when they are implementing Union law" really is. This formula seems to imply a "yes" or "no" question-is EU law applicable? As Advocate-General Bobek pointed out, "in contrast to the question of human existence, $[\ldots]$ the issue of being or not being within the scope of EU law [is not] by definition bipolar: either a case is fully 'in' or it is completely 'out'." ${ }^{37}$ The question, in reality, is more complex - to what extent is EU law applicable? - and the answers are far more nuanced. Thus, any attempt at systematizing the coordinates of the application of the CFREU must give up the quest for the "proverbial unicorn of a clear-cut and predicable test" ${ }^{38}$ regarding Member States.

The combined reading of the Fransson and Melloni judgments on the interpretation of art. 53 CFREU reveals that, under the CFREU, the relevant standard of fundamental rights protection depends on the margin of discretion left by EU law to the Member States (Sarmiento, 2013: 1289). It is worth remembering the terms used: "in a situation where action of the

36 Judgment of the Court in Les Verts, 294/83, EU:C:1986:166, para. 23.

37 Opinion of Advocate General M. Bobek in Ispas, C-298/16, EU:C:2017:650, para. 61.

38 Idem, para. 64. The Advocate General suggests a "lighthouse approach" according to which "the closer to a specific and concrete EU law rule, the less discretion there is on the side of national law. Conversely, the further from the lighthouse, but still touched by its light $[\ldots]$, the less of an intensive review there is". Still, "one point remains clear: where there is light, there must also be shadow (that of EU fundamental rights). If, as a matter of EU law, the Member States are obliged to provide for effective enforcement in the name of EU law, that enforcement must be controlled from the same source, that is, by EU fundamental rights. It would be inconceivable to oblige the Member States to carry out certain activities (...) while the control of and limits to that exercise would suddenly fall outside of the scope of EU law". 
Member States is not entirely determined by European Union law", inasmuch as "an EU legal act calls for national implementing measures", "national authorities and courts remain free to apply national standards of protection of fundamental rights, provided that the level of protection provided for by the Charter, as interpreted by the Court, and the primacy, unity and effectiveness of European Union law are not thereby compromised" ${ }^{39}$. In light of this criterion, two scenarios are conceivable-depending on whether or not the action of Member States is "entirely determined" by EU law. Nevertheless, in light of Siragusa, there is no such clear-cut test as the applicability of the CFREU requires a sufficient link between the situation at issue and the relevant EU ${ } \mathrm{aw}^{40}$. The relevant criterion seems to be one regarding to the intensity of the link between the legal and factual background and the relevant EU law framework (Perez Fernandes, 2017: 56). In that regard, Advocate General Bobek suggests that a certain degree of specificity or proximity is required between the national rule at issue and EU law according to a "rule of (reasonably foreseeable) functional necessity": "any national rule instrumental to the effective realisation of an EU law-based obligation on the national level, even if not specifically adopted for that purpose, will fall within the scope of EU law, unless the adoption and operation of that national rule is not reasonably necessary in order to enforce the relevant EU law" ${ }^{41}$.

\section{THE HARDSHIPS OF SETTING RULES. DECODING THE MEMBER STATES' KEY(S) TO THE CHARTER: A PROPOSAL}

In light of the above, it is proposed to systematize the coordinates of the application of the CFREU to the Member States according to a triple constellation.

1) In a first configuration, the action of Member States is (sufficiently and) entirely determined by EU law, so that the EU legal act in question does not call for national implementing measures - the "complete determination" situation as portrayed by Sarmiento (2013: 1289-1294). Here, the protection of fundamental rights must be assessed in the light of the level of protection guaranteed by EU law, and in particular by the CFREU. In this scenario, national standards of fundamental rights protection will not be applicable, even

39 Judgments of the Court in Fransson, C-617/10, EU:C:2013:105, para. 29, and Melloni, C-399/11, EU:C:2013:107, para. 60 (emphasis added).

40 Judgment of the Court in Siragusa, C-206/13, EU:C:2014:126, para. 24.

41 Opinion of Advocate General M. Bobek in Ispas, C-298/16, EU:C:2017:650, para. 45-51 and 55-57. 
if they determine a higher level of protection than the one guaranteed under the CFREU (Ward, 2014: 1419). That was the case in Melloni. The provision of EU law in question left no discretion to Member States for the execution of a European arrest warrant ${ }^{42}$. It was therefore not possible, on the basis of art. 53 CFREU, to make the execution of a warrant subject to the respect for fundamental rights as guaranteed by the constitution of the executing Member State ${ }^{43}$.

In these cases, the EU legal act already reflects a consensus on the level of fundamental rights protection to be respected in its scope of application: when adopting the act in question, the EU legislator weighted the general interests of the EU pursued and the protection of fundamental rights and, in compliance with the CFREU ${ }^{44}$, established the level of protection applicable; therefore, the application of national standards of fundamental rights protection, albeit higher, would compromise the primacy, unity and effectiveness of EU law (Lenaerts and Gutiérrez-Fons, 2014: 1591). As a result, the EU responsibility for the protection of fundamental rights is increased: if the EU, through its own political and legislative procedures ${ }^{45}$, uniformly sets the level of fundamental rights protection to be respected in a certain field, it must provide a high level of protection in order to reconcile the primacy, unity and effectiveness of EU law and the necessary protection of the fundamental rights of the individuals likely to be affected by the application of the EU legal act in question.

2) On the contrary, in situations of "partial determination" (Sarmiento, 2013: 1294-1296), the action of Member States is (sufficiently but) not entirely determined by EU law, as the EU legal act in question does call for national implementing measures. In this scenario, the application of national standards of fundamental rights protection is possible. In these cases, just as the action of Member States is governed in a complementary way both by the EU legal order and by their respective national legal orders, the same applies to the protection of fundamental rights. That was the case in Fransson: in

42 Art. 4a(1) of Council Framework Decision 2002/584/JHA of 13 June 2002 on the European arrest warrant and the surrender procedures between Member States, OJ L 190, 18.7.2002, pp. 1-20.

43 Judgment of the Court in Melloni, C-399/11, EU:C:2013:107, para. 40 and 61-64.

44 In Melloni the ECJ examined art. 4a(1) of Framework Decision 2002/584 in light of the fundamental rights guaranteed by arts. 47 and 48(2) CFREU, concluding that the former did not disregard the requirements arising therefrom-judgment of the Court in Melloni, C-399/11, EU:C:2013:107, para. 47-54.

45 Procedures in which the Member States participate, as outlined in the judgment of the Court in Melloni, C-399/11, EU:C:2013:107, para. 62. 
so far as EU law recognises a certain margin of discretion to Member States in complying with their obligation to counter illegal activities affecting the financial interests of the EU through effective deterrent measures, so that, in particular, national (criminal) law was at the service of the objectives laid down by EU law in relation to VAT, it is possible, on the basis of art. 53 CFREU, for national authorities and courts to apply national standards of fundamental rights protection ${ }^{46}$. Furthermore, since derogations imposed by Member States to the exercise of economic fundamental freedoms and the conditions those derogations must comply with in order to be considered legitimate, are "creatures" of EU law (Weiler and Fries, 1999: 25), the so-called "derogation situations" are also to be considered within this second scenario, which the ECJ confirmed in Pfleger and Berlington Hungary ${ }^{47}$.

Thus, where EU law leaves a certain margin of discretion to Member States, (i) both the CFREU and national standards of fundamental rights protection are to be concurrently considered, (ii) being applicable in a particular case, under art. $53 \mathrm{CFREU}^{48}$, the standard offering a higher level of protection $^{49}$. Such deference towards higher standards of fundamental rights

46 Judgment of the Court in Fransson, C-617/10, EU:C:2013:105, para. 25-29.

47 Judgments of the Court in Pfleger, C-390/12, EU:C:2014:281, para. 31-36; and in Berlington Hungary, C-98/14, EU:C:2015:386, para. 74 and 113.

48

It could be argued, in light of the wording employed in Fransson and Melloni, that national authorities and courts are not, under EU law, obliged to apply national standards of fundamental rights protection, but only "remain free" to do so- - and, consequently, that such an obligation solely stems from national law, in particular national constitutional law. However, considering exclusively national law, and not (also) EU law via art. 53 CFREU, as the sole legal basis for the application of national standards of fundamental rights protection, would allow an interpretation of art. 53 CFREU as restricting or adversely affecting fundamental rights as recognised by the Member States' constitutions in their respective fields of application when these are concurrent with EU law. The above mentioned position admits the following legal-constitutional constellation: national authorities and courts would "remain free" to apply only the CFREU in all situations falling within the scope of application of EU law, even those sufficiently but not entirely covered by EU law, with the exclusion of any national constitutional provision providing for higher levels of protection; in these terms, situations covered by EU law according to the second scenario described in text would be treated less favourably (solely in the light of the CFREU) than similar situations of a strictly domestic nature (which would benefit from higher levels of protection provided for under national constitutional law).

49 The highest level of protection should be assessed from the point of view of the individual in relation to public authority, the highest level of protection therefore being that which is more favourable to the individual, extending their sphere of autonomy 
protection under national law shows how, even when EU law applies for the purposes of art. 51(1) CFREU, there is still room for national standards of fundamental rights protection in light of art. 53 CFREU in situations not entirely determined by EU law. However, the application of national standards of protection of fundamental rights is not absolute. The "level of protection provided for by the Charter, as interpreted by the Court" is not to be compromised and will be applicable in a particular case if it offers a higher level of protection, i.e., national standards of fundamental rights protection should ensure a higher level of protection than the one guaranteed under the CFREU in order to be applied under art. 53 CFREU (positive condition). Moreover, in this context, the interpretation given by the ECJ to art. 53 CFREU does not forego the "primacy, unity and effectiveness of European Union law" (negative condition). Thus, in the event that national standards of fundamental rights protection do offer a higher level of protection than the one resulting from the CFREU, the CFREU will nevertheless apply in order to safeguard structuring principles of EU law (Sarmiento, 2013: 1295) or the objectives pursued by the EU in that field (Lenaerts and Gutiérrez-Fons, 2014: 1591).

3) To these two types of situations a third one is to be added referring to situations which fall outside the scope of application of EU law. In light of the above, rather than only situations of a strictly domestic nature, this third scenario also includes situations not sufficiently determined by EU law. The solution has been applied by the ECJ in cases such as Siragusa ${ }^{50}$, Julian Hernández $^{51}$, Willems ${ }^{52}$ and $X$ and $X^{53}$, on the basis of a somewhat restrictive understanding of the concept of "[scope of] application of EU law". In any case, it follows from the ECJ case-law that these "legal areas free of EU law" (Platon, 2012: 26) correspond to "legal areas free of the CFREU". Thus, national standards of fundamental rights protection will apply, even in the event of ensuring a lower level of protection than the one guaranteed under the CFREU, and subject to their control in the light of the ECHR ${ }^{54}$.

The persistence of the criterion of the application of EU law to trigger the application of the CFREU to Member States - which can only be withdrawn

vis-à-vis the State, or giving them more guarantees in certain situations (Canotilho, 2013: 607-608 and 623-624).

50 Judgment of the Court in Siragusa, C-206/13, EU:C:2014:126, para. 24-36.

51 Judgment of the Court in Julian Hernández, C-198/13, EU:C:2014:2055, para. $37-$ 47.

52 Judgment of the Court in Willems, C-446/12 to C-449/12, EU:C:2015:238, para. 47-51.

53 Judgment of the Court in X and X, C-638/16 PPU, EU:C:2017:173, para. 43-45.

54 Judgment of the Court in F., C-168/13 PPU, EU:C:2013:358, para. 48. 
by means of a revision of the Treaties-reveals that the EU is not willing to monopolize the control of respect for fundamental rights in the exercise of public power by the Member States, as situations exist which fall outside the scope of application of EU law and, thus, of the CFREU. Member States may nevertheless regard the CFREU as applicable in situations without (sufficient) connection with EU law. The constitutions of some Member States provide for opening clauses for other instruments of fundamental rights protection ${ }^{55}$. But, given the method emerging from EU constitutionalism, and without compromising the constitutional autonomy of the legal orders involved, it is argued that such practice should be followed in the field of fundamental rights protection even without explicit provision in national constitutional law.

To that extent, the third scenario should not be conceived as the exact opposite of the first. In the first scenario, the application of national standards of fundamental rights protection, even when higher, is excluded to situations entirely determined by EU law. In this third scenario, the application of the CFREU would not be excluded as long as the level of protection provided for under the CFREU is higher than the one resulting from national standards of fundamental rights protection. Therefore, this friendly openness of domestic constitutional legal orders to the CFREU would have a limit: the application of the CFREU, as interpreted by the ECJ, is to be excluded when it entails applying a lower level of protection for a specific fundamental right, leading to a less favourable outcome than that would result of the exclusive application of national standards of fundamental rights protection (Rodríguez Portugués, 2016: 73-90). Thus, the constitutional autonomy of national legal systems for the protection of fundamental rights is preserved since they "should not be applied and interpreted 'downwards' by invoking the language of the Charter" (de Witte, 2014: 1525). It should be noted that this guarantee results from the standstill clause implicitly enshrined in art. 53 CFREU according to which the CFREU shall not be interpreted as restricting or adversely affecting the fundamental rights as recognised, "in their respective fields of application" by EU law, by international agreements to which the EU or the Member States are party, and by the Member States' constitutions, a rule "intended to maintain the level of protection currently afforded within their respective scope" ${ }^{17}$ by each of the sources that integrate the whole.

55 Such as art. 16 of the Constitution of the Portuguese Republic.

56 Explanations relating to art. 53 CFREU (emphasis added).

57 Idem. 
As we have tried to demonstrate, determining "just how 'EU-heavy' the subject matter of the litigation need to be before it comes to be governed by the Charter" (Ward, 2014: 1452), whether entirely determined by EU law, or determined both by EU law and national law in a complementary way, or not at all (or rather, not sufficiently) determined by EU law, continues to be a case-by-case work in progress. Given the interdependence between the legal orders involved - that of the Union and those of the Member Statesand the consequent fluidity in the delimitation of their borders, that is the inevitable result. This is not, however, the most satisfactory result from the point of view of legal certainty and the sense of predictability in the field of fundamental rights protection which the CFREU, in particular through the provisions of its Title VII, was intended to ensure. It is a result which largely depends on a case-by-case approach ${ }^{58}$ and, specifically, on the unpredictability of the private life of the individuals involved in each particular case and at any given moment. Though the pluralism of sources that integrate the EU system of fundamental rights protection should not undermine the transparency of said system, composing a systematic construction of the rules governing the

58 The judgment of the Court in JZ, C294/16 PPU, EU:C:2016:610, provides such an example. The case concerned the obligation under art. 26(1) of Framework Decision 2002/584 according to which the issuing Member State (Poland) is to deduct from the total period of detention to be served all periods of detention arising from the execution of a European arrest warrant served in the executing Member State (United Kingdom). Taking also into consideration relevant ECtHR case-law (para. 48-52), the ECJ interpreted the concept of "detention" as "covering not only imprisonment but also any measure or set of measures imposed on the person concerned which, on account of the type, duration, effects and manner of implementation of the measure(s) in question deprive the person concerned of his liberty in a way that is comparable to imprisonment" (para. 47). In the case at hand, the judicial authority of the issuing Member State was required to consider whether the measures taken against $\mathrm{JZ}$ in the executing Member State were to be treated in the same way as a deprivation of liberty. That being the case "art. 26(1) of Framework Decision 2002/584 requires" that the whole of the period during which those measures were applied be deducted from the period of detention to be served in the issuing Member State (para. 53, emphasis added) — complete determination situation. On the contrary, if those measures were not so restrictive of that person's liberty of movement as to have the effect of depriving him of his liberty (and it did not seem to be the case-para. 54-), it would be "on the basis of domestic law alone" that the judicial authority of the issuing Member State would deduct, or not, from the total period of detention to be served all or part of the period during which that person was subject, in the executing Member State, to measures involving not a deprivation of liberty but a restriction of it (para. 55, emphasis added)_-legal area free of EU law. 
application of the CFREU to Member States still belongs to the world of proposals and ultimately raises more questions than it provides answers (Iglesias Sánchez, 2012: 1609; Ward, 2014: 1452-1453).

\section{THE TARICCO SAGA AS A CASE STUDY}

\section{TARICCO I. A BRIEF OVERVIEW}

As interpreted in Fransson and Melloni, the principle of the highest level of protection enshrined in art. 53 CFREU has its limits. Firstly, the principle does not apply in a situation entirely determined by EU law. In this scenario, and even if they provide for a higher level of protection than the one guaranteed under the CFREU, the application of national standards of fundamental rights protection would call into question "the uniformity of the standard of protection of fundamental rights" 59 as defined by a EU legal act that does not call for national implementing measures, thereby undermining the unity, primacy and effectiveness of EU law. Secondly, the principle is not operative or is neutralised when, in a situation not entirely determined by EU law, the application of national standards of fundamental rights protection, albeit higher than the levels of protection guaranteed under EU law, particularly under the CFREU, compromise the unity, primacy and effectiveness of EU law ${ }^{60}$.

This is explained by the circumstance that fundamental rights protection within the EU legal order is ensured "within the framework of the structure and objectives of the EU"61 in view of the European integration process. The $\mathrm{EU}$ was not created for the protection of fundamental rights, in the likeness of the neighboring Council of Europe, but rather to carry out an integration process. Consequently, and in particular, the ECJ is not a jurisdiction for the protection of fundamental rights, but rather the jurisdiction of the European integration process and must therefore balance the structure and the objectives of the EU with the protection of fundamental rights. That is why the principle of the highest level of protection of fundamental rights enshrined in art. 53 CFREU and as interpreted by the ECJ seeks to accommodate the legal pluralism which constitutes the EU system of fundamental rights protection for the benefit of the individuals interested in the protection of their

59 Judgment of the Court in Melloni, C-399/11, EU:C:2013:107, para. 63.

60 Judgment of the Court in Fransson, C-617/10, EU:C:2013:105, para. 29.

61 Opinion of the Court 2/13 (Accession of the EU to the ECHR), EU:C:2014:2454, para. 170 . 
fundamental rights (pro individual) without underminig the unity, primacy and effectiveness of EU law (pro integration).

The Taricco saga demonstrates just how delicate is the mission, not only to maintain, but also to build such balance. In Taricco ${ }^{62}$ the ECJ had the opportunity to detail the scope of Member States' obligations to fight against VAT evasion following the case-law established in Fransson ${ }^{63}$. Referring especially to art. 325 TFEU, the ECJ specified that, although Member States have "freedom to choose the applicable penalties", EU law imposes on them a "precise obligation as to the result to be achieved" which is to counter illegal activities affecting EU financial interests "through dissuasive and effective measures" and, to this end, "to take the same measures to counter fraud affecting those interests as they take to counter fraud affecting their own financial interests" "64. However, the Italian legal rules on limitation in criminal matters were such that, given the complexity and duration of criminal proceedings, defendants accused of committing offences in relation to VAT constituting serious fraud affecting EU financial interests were likely to benefit from de facto impunity on account of the expiry of the limitation periods-"a normal, rather than exceptional, occurrence" in Italy as reported by the referring court $^{65}$. Thus, the ECJ held to be incompatible with EU law, namely with art. 325(1) TFEU, the application of national rules on limitation in criminal matters that "[have] the effect that, in a considerable number of cases, the commission of serious fraud will escape criminal punishment, since the offences will usually be time-barred before the criminal penalty laid down by law can be imposed by a final judicial decision"; additionally, and subject to verification by the national court, the ECJ held that it would be incompatible with art. 325(2) TFEU the application of a national rule on limitation periods to cases of VAT evasion in another manner than it applies to cases of fraud affecting only the Italian Republic's financial interests ${ }^{66}$.

However, the ECJ went further-and here lies the legal friction point underlying the long-awaited Taricco II judgment ${ }^{67}$. The ECJ accompanied this interpretation of art. 325 TFEU (hereinafter, "Taricco interpretation of art. 325 TFEU") with a specific obligation for the national courts (hereinafter,

62 Judgment of the Court in Taricco I, C-105/14, EU:C:2015:555.

63 Judgment of the Court in Fransson, C-617/10, EU:C:2013:105, para. 25-27.

64 Judgment of the Court in Taricco I, C-105/14, EU:C:2015:555, para. 37, 39-41, 43 and $50-51$.

65 Judgment of the Court in Taricco I, C-105/14, EU:C:2015:555, para. 24.

66 Judgment of the Court in Taricco I, C-105/14, EU:C:2015:555, para. 47 and 48.

67 Judgment of the Court in M.A.S. and M.B. (Taricco II), C42-17, EU:C:2017:936. 
"Taricco obligation under art. 325 TFEU"). Since the national provisions at issue were to be considered incompatible with EU law, national courts were required to apply the sanction of primacy. Thus, the ECJ interpreted art. 325 TFEU as having "the effect, in accordance with the principle of the precedence of EU law, in their relationship with the domestic law of the Member States, of rendering automatically inapplicable, merely by their entering into force, any conflicting provision of national law"; as a consequence, the national court "would have to ensure that EU law is given full effect, if need be by disapplying those provisions [...], without having to request or await the prior repeal of those articles by way of legislation or any other constitutional procedure" 68 . The ECJ added that, if the national court decides to disapply the national provisions at issue, "it must also ensure that the fundamental rights of the persons concerned are respected", since penalties may be imposed on them which, in all likelihood, would not have been if those provisions of national law had been applied ${ }^{69}$. In that regard, the ECJ did not consider that the disapplication of the national provisions at issue would infringe the rights of the accused as guaranteed by art. 49 CFREU which enshrines the principles of legality and proportionality of criminal offences and penalties ${ }^{70}$.

Stating that the Taricco I judgment caused some stir within the Italian legal community would be an understatement. Ultimately, and a few days after the ECJ gave its judgment, the Court of Appeal of Milan, instead of applying the solution contained therein in compliance with the 'Taricco obligation under art. 325 TFEU', decided to stay the proceedings and to refer a question of constitutionality to the Italian Constitutional Court (ICC), a decision that would also be taken by the Italian Court of Cassation a few months later. Both courts expressed doubts as to the compatibility of the case-law established in Taricco I with supreme principles of the Italian constitutional order and with observance of the inalienable rights of the individual as laid down by the Italian Constitution, with particular reference to the principle of legality in criminal matters.

Hearing such concerns, the ICC sought a preliminary reference from the $\mathrm{ECJ}^{71}$ according to an expedited procedure, the application of which was deferred $^{72}$. The questions referred for a preliminary ruling sought clarification

68 Judgment of the Court in Taricco I, C-105/14, EU:C:2015:555, para. 52 and 49.

69 Judgment of the Court in Taricco I, C-105/14, EU:C:2015:555, para. 53.

70 Judgment of the Court in Taricco I, C-105/14, EU:C:2015:555, para. 54-57.

71 Order of the Corte Costituzionale (Constitutional Court), No. 24/2017, IT:COST: 2017:24.

72 Order of the Court in M.A.S. e M.B., C-42/17, EU:C:2017:168. 
of the 'Taricco obligation under art. 325 TFEU'. The ICC sought to ascertain whether such an obligation is imposed (i) "even where there is no sufficiently precise legal basis for such disapplication"; (ii) "even where, in the legal system of the Member State concerned, limitation periods form part of substantive criminal law and are subject to the principle of the legality of criminal proceedings"; and (iii) "even where such disapplication is at variance with the overriding principles of the constitution of the Member State concerned or with the inalienable rights of the individual conferred by the constitution of the Member State".

\section{TARICCO II. A CRITICAL ANALYSIS}

It is, at first, to value the constitutional deference shown by the ICC, which, paraphrasing a popular saying ${ }^{73}$, did not keep the stone in the bootespecially because, regardless of the outcome, Taricco II was surely to become a gemstone. Indeed, even if deciding in a dialogue with the ICC, the ECJ had to consider the impact of its decision on a broader scale both in space, also having as real interlocutors all the courts, whether constitutional, supreme or other, from all Member States, and in time, also with a view to solving potential similar situations that might occur in the future.

After setting the tone to the beat of judicial dialogue and cooperation provided by the preliminary ruling mechanism ${ }^{74}$, the ECJ observes on a preliminary note that the questions raised by the ICC were not intended to call into question the 'Taricco interpretation of art. 325 TFEU', but rather to clarify $\mathrm{it}^{75}$. The preliminary ruling procedure initiated by the ICC is thus welcomed as an opportunity for the ECJ to further elaborate on the interpretation of that provision in light of certain elements that had not been known to the ECJ at the time in which Taricco I was given-i.e., the ECJ is prudent but not omniscient ${ }^{76}$. In Taricco II, the ECJ specially emphasised that the burden of compliance with the 'Taricco interpretation of art. 325 TFEU' lies with

73 The Portuguese expression in question is pedra no sapato (literally, 'stone in the shoe'), an expression commonly used to refer to a difficulty imposed by third parties that makes difficult the accomplishment of a certain objective.

74 Judgment of the Court in M.A.S. and M.B. (Taricco II), C-42/17, EU:C:2017:936, para. 22-23.

75 Judgment of the Court in M.A.S. and M.B. (Taricco II), C-42/17, EU:C:2017:936, para. 24-28.

76 Arguably, "an excuse to provide a different assessment of the situation that arose in Italy” (Krajewski, 2017). 
the national legislature ${ }^{77}$. It is not only for the national legislature to adopt effective and deterrent measures in the form of criminal penalties for cases of serious fraud affecting EU financial interests in relation to VAT, but also to lay down rules on limitation that enable compliance with the obligations arising from the 'Taricco interpretation of art. 325 TFEU', thus ensuring that "the national rules on limitation in criminal matters do not lead to impunity in a significant number of cases of serious VAT fraud, or are more severe for accused persons in cases of fraud affecting the financial interests of the Member State concerned than in those affecting the financial interests of the European Union"78. The ECJ also recalled that an extension of a limitation period by the national legislature and its immediate application, including to alleged offences that are not yet time-barred, do not, in principle, infringe the principle of legality in criminal matters enshrined in art. 49 CFREU as interpreted in Taricco $\Gamma^{79}$.

The litigious point then concerned compliance with the 'Taricco obligation under art. 325 TFEU' by national courts. Its origin lies in paragraph 53 of the Taricco I judgment which attaches the principle of primacy of EU law with the protection of fundamental rights by placing national courts at the centre of such crossroads. It follows from that recital that where, under the principle of primacy of EU law, a national court decides to disapply national provisions contrary to EU law, "it must also ensure that the fundamental rights of the persons concerned are respected"so. Nevertheless, the ECJ neglected to specify how or to what extent. The ECJ merely sought to associate national courts with its (constitutional) mission of protecting fundamental rights within the framework of the pluralist but inclusive EU system of fundamental rights protection-which explains that, in the following recitals, the ECJ not only refers but rather interprets art. 49 CFREU, in particular in light of relevant ECtHR case-law ${ }^{81}$. The message underlying the above-mentioned recital is as follows: as national courts are "[EU] courts of general jurisdiction" 82 , when they decide to disapply provisions of national law incompatible with

77 Judgment of the Court in M.A.S. and M.B. (Taricco II), C-42/17, EU:C:2017:936, para. 32-36.

78 Judgment of the Court in M.A.S. and M.B. (Taricco II), C42/17, EU:C:2017:936, para. 41.

79 Judgment of the Court in M.A.S. and M.B. (Taricco II), C42/17, EU:C:2017:936, para. 42.

80 Emphasis added. See, also, judgment of the Court in M.A.S. and M.B. (Taricco II), C42/17, EU:C:2017:936, para. 46.

81 Judgment of the Court in Taricco I, C-105/14, EU:C:2015:555, para. 54-57.

82 Judgment of the General Court in Tetra Pak, T-51/89, EU:T:1990:41, para. 42. 
EU law, it is also in their capacity as European courts that they must ensure the protection of fundamental rights in such circumstances. The approach is consistent with the one outlined in the case-law analysed above. Where national courts disapply provisions of national law in order to "ensure that EU law is given full effect" 83 , they are implementing EU law within the meaning of art. 51(1) CFREU, so that fundamental rights protection must be ensured in accordance with EU law, particularly with the CFREU, and thus must operate "within the framework of the structure and objectives of the EU" ${ }^{84}$. The underlying message is that both the ECJ and national courts are jurisdictions of the European integration process and must balance the objectives of the $\mathrm{EU}$ with fundamental rights protection.

And so proceeded the ICC in making a request for a preliminary ruling to the ECJ-instead of giving in to the application of its counter-limits doctrine (Bassini and Pollicino, 2017a) and disapplying EU law (the Taricco I judgment) in order to safeguard national constitutional principles and fundamental values. Specifically, in its order for reference, the ICC gives an account of its interpretation of said recital, or rather its "conviction", that "the intention in making these assertions was to state that the rule inferred from art. 325 TFEU is only applicable if it is compatible with the constitutional identity of the Member State, and that it falls to the competent authorities of that State to carry out such an assessment" ${ }^{\prime 5}$. The ICC seems to consider that the ECJ has delegated to national courts the task of assessing the compatibility of the 'Taricco obligation under art. 325 TFEU' with supreme principles of the Italian constitutional order and the observance of inalienable rights of the individual as laid down by the Italian Constitution, in order to preserve the national constitutional identity. To that end, the ICC explains that, according to Italian constitutional law, the rules on limitation in criminal matters are substantive (rather than procedural) in character and therefore fall within the scope of the principle of legality in criminal matters, principle which is an "expression of a supreme principle of the legal order, which has been posited in order to safeguard the inviolable rights of the individual" ${ }^{86}$. Under the principle of legality in criminal matters as conceived in the Italian constitutional

83 Judgment of the Court in Taricco I, C-105/14, EU:C:2015:555, para. 49.

84 Opinion of the Court 2/13 (Accession of the EU to the ECHR), EU:C:2014:2454, para. 170.

85 Order of the Corte Costituzionale (Constitutional Court), No. 24/2017, IT:COST: 2017:24, para. 7.

86 Order of the Corte Costituzionale (Constitutional Court), No. 24/2017, IT:COST: 2017:24, para. 2 and 4 . 
order, individuals enjoy the right $\mathrm{t}^{87} /$ legitimate expectation of not to be punished beyond the limitation period applied at the time of the offence. On the contrary, fulfilment with the 'Taricco obligation under art. 325 TFEU' would entail the disapplication of the relevant national provisions on limitation periods, with the consequence that defendants would be punished beyond the limitation period applicable at the time of the offence.

This is a peculiar approach to the principle of legality in criminal matters, which is not shared by all Member States, of which the ICC is aware of ${ }^{88}$; some Member States have in fact adopted a procedural approach to limitation periods, an approach to which the reasoning followed by the ECJ in Taricco I, supported by case-law of the ECtHR, seems also more closely related ${ }^{89}$. However, the qualitative leap towards national constitutional identity remains unclear. The ICC does not explain to what extent that approach to the principle of legality in criminal matters is an integral part of the constitutional identity of the Italian Republic, that is, the reasons for such an approach to be considered one of the "overriding' or 'fundamental' principles of the constitutional order [...] which identify the constitutional order and represent the 'hard core' of the Italian Constitution" ${ }^{\prime 2}$. The Member States' national constitutional identity reflects nuclear national features inscribed in their constitutional genetic code, in the self-understanding which each Member State conceives of the specificities which form the essential core of their "self" (Silveira and Perez Fernandes, 2017a: 19-22). As previous ECJ case-law demonstrates, not every principle of the national constitutional order of a Member

87 As Advocate General Bot explains, as limitation rules fall within the scope of that principle under Italian constitutional law, "every individual has the right to know, before he commits a wrongful act, whether that act is an offence, the penalty and the limitation period applicable to it" and, therefore, the offender "has a vested right that the entire proceedings should take place according to the limitation rules as they existed on the day on which he committed the offence"-see Opinion of Advocate General Y. Bot in M.A.S. and M.B. (Taricco II), C-42/17, EU:C:2017:564, para. 66 and 76.

88 Order of the Corte Costituzionale (Constitutional Court), No. 24/2017, IT:COST: 2017:24, para. 4.

89 Judgment of the Court in Taricco I, C-105/14, EU:C:2015:555, para. 56 and 57. This is also the understanding followed in the Opinion of Advocate General J. Kokott in Taricco I, C-105/14, EU:C:2015:293, para. 115 and 119-120. For an account of the relevant case-law of the ECtHR, see Opinion of Advocate General Y. Bot in M.A.S. and M.B. (Taricco II), C-42/17, EU:C:2017:564, para. 127-140.

90 Referring to a judgment of the ICC, see Opinion of Advocate General Y. Bot in M.A.S. and M.B. (Taricco II), C-42/17, EU:C:2017:564, para. 184. 
State triggers the application of art. 4(2) TEU (Perez Fernandes, 2013: 148164). As for the case under analysis ${ }^{91}$, we are not convinced that a different understanding regarding the principle of legality in criminal matters would undermine the national (constitutional) identity of the Italian Republic - the Italian Republic would not cease to be as we know it, nor as the own Italian Republic knows itself, with the application of a longer limitation period.

What was at stake was a certain level of protection for a fundamental right that the Italian Republic sought to ensure-a matter of constitutional differentiation rather than an attack on constitutional identity. And so, the ECJ did not provide for an answer for the third question raised by the ICC $^{92}$. Albeit not expressly referring to art. 53 CFREU, the reasoning followed by the ECJ can be considered in light of its interpretation in Fransson and Melloni ${ }^{93}$. When a situation is not entirely determined by EU law ${ }^{94}$, thus falling under the second scenario described above, it follows from that case-law that the application of national standards of fundamental rights protection is subject to two conditions: $(i)$ the guarantee of a higher standard of protection than that resulting from the CFREU (positive condition) and (ii) the safeguard of the primacy, unity and effectiveness of EU law (negative condition).

According to the ICC, the first condition would be fulfilled as, under the Italian constitutional order, the principle of legality in criminal matters entails that the limitation periods in force at the time of the offence remain unchanged throughout the proceedings ${ }^{95}$-i.e., what was foreseeable remains stable. In turn, the ECJ was in need to further elaborate in Taricco II on

91 See Opinion of Advocate General Y. Bot in M.A.S. and M.B. (Taricco II), C-42/17, EU:C:2017:564, para. 176-187.

92 Judgment of the Court in M.A.S. and M.B. (Taricco II), C-42/17, EU:C:2017:936, para. 63.

93 Only the interpretation given to art. 53 CFREU in Fransson, C-617/10, EU:C: 2013:105, para. 29, and Melloni, C-399/11, EU:C:2013:107, para. 60, is referred in M.A.S. and M.B. (Taricco II), C-42/17, EU:C:2017:936, para. 47.

94 Judgment of the Court in M.A.S. and M.B. (Taricco II), C-42/17, EU:C:2017:936, para. 44-47.

95 In the words of the ICC, "[the] Italian Constitution construes the principle of legality in criminal matters more broadly than European law as it does not limit itself to describing the conduct constituting the offence and the penalty, but rather covers all substantive aspects of liability to punishment", including limitation periods; therefore "this classification entails a higher level of protection than that granted to accused persons by article 49 [CFREU]" and "must therefore be considered to be safeguarded by EU law itself, pursuant to article 53 of the Charter read also in the light of the 
the principle of legality in criminal matters. First, the ECJ interprets art. 49 CFREU considering the three pillars of foreseeability, precision and nonretroactivity inherent to the principle, namely in light of relevant ECtHR case-law. Here, the ECJ adopted an internormative approach regarding the principle of legality in criminal matters and valued its importance as a principle shared by all Member States both as a common constitutional tradition and a principle enshrined in various international treaties, in particular in art. 7(1) ECHR ${ }^{96}$. Then, the ECJ acknowledges the differentiation proper to the Italian legal order: "the requirements of foreseeability, precision and non-retroactivity inherent in the principle that offences and penalties must be defined by law apply also, in the Italian legal system, to the limitation rules for criminal offences relating to VAT"97. Indeed, at the relevant time, the Italian Republic was, in the absence of harmonisation at EU level ${ }^{98}$, free to provide that rules on limitation formed part of substantive criminal law and were therefore subject to that principle ${ }^{99}$.

It is, however, in drawing consequences from this framework to the issues at hand that the reasoning of the ECJ in Taricco II is difficult to follow. In addition to the wording of the judgment being rather tangled ${ }^{100}$, as both art. 53 CFREU and its interpretation in case-law are absent in this part of the judgment, the ECJ does not acknowledge whether or not the Italian understanding of the principle of legality in criminal matters provides for a higher level of protection than that resulting from art. 49 CFREU and, therefore, prevails under art. 53 CFREU (Burchardt, 2017).

related explanation"- - see Order of the Corte Costituzionale (Constitutional Court), No. 24/2017, IT:COST:2017:24, para. 8.

96 Judgment of the Court in M.A.S. and M.B. (Taricco II), C-42/17, EU:C:2017:936, para. 51-57.

97 Judgment of the Court in M.A.S. and M.B. (Taricco II), C-42/17, EU:C:2017:936, para. 58.

98 To a certain extent, harmonisation has since taken place-see art. 12 of Directive (EU) 2017/1371 of the European Parliament and of the Council of 5 July 2017 on the fight against fraud to the Union's financial interests by means of criminal law, OJ L 198, 28.7.2017, pp. 29-41.

99 Judgment of the Court in M.A.S. and M.B. (Taricco II), C-42/17, EU:C:2017:936, para. 45.

100 The consultation of several language versions of the judgment, namely in French (language of deliberation), Italian (language of the case), Spanish (main language of this publication) and Portuguese (language of the Author), in addition to the English version of the judgment (language of the text), corroborates the statement. 
In overview, it follows from Taricco II that fulfilment with the 'Taricco obligation under art. 325 TFEU' by national courts has its limits in light of the principle of legality in criminal matters: when answering the questions referred for a preliminary ruling, the ECJ reiterated that obligation to disapply national provisions on limitation, even when "forming part of national substantive law", "unless that disapplication entails a breach of the principle that offences and penalties must be defined by law because of the lack of precision of the applicable law or because of the retroactive application of legislation imposing conditions of criminal liability stricter than those in force at the time the infringement was committed"101. Therefore, if national courts were to find that disapplying the national rules on limitation would lead, in the Italian legal system, to a situation of uncertainty and/or to the retroactive application of legislation imposing conditions of criminal liability stricter than those in force at the time of the offence, then they "would not be obliged to comply"102 with the "Taricco obligation under art. 325 TFEU'103.

A closer reading of the ruling, however, leads to a different interpretation of the reasoning underlying each of the precision and non-retroactivity requirements inherent to the principle of legality in criminal matters.

With regard to the requirement of precision, the ECJ holds that it is for the national court to ascertain whether compliance with the 'Taricco obligation under art. 325 TFEU' would "lead to a situation of uncertainty in the Italian legal system as regards the determination of the applicable limitation rules" 104 . It is our understanding that, here, the ECJ gives effect to the differentiation proper to the Italian legal order previously acknowledged. According to the ECJ, the requirement of precision inherent to the principle of legality in criminal matters as conceived under EU law "is met where the individual is in a position, on the basis of the wording of the relevant provision and if necessary with the help of the interpretation made by the courts, to know which acts or omissions will make him criminally liable"105_but not until when his/ her criminal liability extends. However, as the requirement of precision also applies, in the Italian legal order, to the limitation rules for criminal offences

101 Judgment of the Court in M.A.S. and M.B. (Taricco II), C-42/17, EU:C:2017:936, para. 62 (emphasis added).

102 Judgment of the Court in M.A.S. and M.B. (Taricco II), C-42/17, EU:C:2017:936, para. 61.

103 Admittedly, a "magical formulation” (Budinska and Vikarska, 2017).

104 Judgment of the Court in M.A.S. and M.B. (Taricco II), C-42/17, EU:C:2017:936, para. 59.

105 Judgment of the Court in M.A.S. and M.B. (Taricco II), C-42/17, EU:C:2017:936, para. 56. 
relating to VAT, it is for the national court to ascertain whether compliance with the 'Taricco obligation under art. 325 TFEU' would lead to a situation of uncertainty in breach of the principle of legality in criminal matters. That being the case, the national court "is not obliged to disapply" the national provisions on limitation periods ${ }^{106}$. Although not mentioned, the principle of the highest level of protection of fundamental rights enshrined in art. 53 CFREU, as interpreted in case-law, appears to have been operative: as the principle of legality in criminal matters under the Italian legal order provides for a higher level of protection than under EU law, the national standard of protection is to be applied under art. 53 CFREU. Only in spirit (and controversially ${ }^{107}$ ) this rationale was present.

As to the requirement of non-retroactivity, the ECJ holds that it "preclude(s) the national court, in proceedings concerning persons accused of committing VAT infringements before the delivery of the Taricco judgment, from disapplying the [national] provisions [...] at issue". The ECJ had already pointed out in Taricco I that "if those provisions were disapplied, penalties might be imposed on those persons which, in all likelihood, would not have been imposed if those provisions had been applied"; as a result, those persons could be made retroactively subject to conditions of criminal liability stricter than those in force at the time of the offence ${ }^{108}$. Though not clear from the recital $^{109}$, it is our view that the ECJ refers to the requirement of non-retroactivity (also) as conceived under EU law: contrary to the previous requirement, there is no reference to an assessment to be made by the national court and the ECJ reiterates its ruling in Taricco I on the issue. Furthermore, in Taricco $I I$, the ECJ specified that the requirement of non-retroactivity inherent to the principle of legality in criminal matters as conceived under EU law precludes courts in the course of criminal proceedings from "[aggravating] the rules on

106 Judgment of the Court in M.A.S. and M.B. (Taricco II), C-42/17, EU:C:2017:936, para. 59.

107 For an opposite view, see Krajewski (2017).

108 Judgments of the Court in Taricco I, C-105/14, EU:C:2015:555, para. 58, and M.A.S. and M.B. (Taricco II), C-42/17, EU:C:2017:936, para. 60.

109 Judgment of the Court in M.A.S. and M.B. (Taricco II), C-42/17, EU:C:2017:936, para. 60. The ECJ refers to para. 58 which reads as follows: "As noted in paragraph 45 above, the requirements of foreseeability, precision and non-retroactivity inherent in the principle that offences and penalties must be defined by law apply also, in the Italian legal system, to the limitation rules for criminal offences relating to VAT”. Therefore, in para. 60, it is unclear whether the ECJ refers to the Italian or the EU understanding of the principle of legality in criminal matters. 
criminal liability of those against whom such proceedings are brought"110. Therefore, and importantly, there is no dissonance between the Italian and the EU understanding of this requirement to be settled as a matter of higher level of protection, but simply unison as to the level of protection to be guaranteed.

There is, however, a temporal limitation (Krajewski, 2017) to the enfranchisement of national courts from the "Taricco obligation under art. 325 TFEU", a temporal limitation which subtly results from the Taricco II judgment, but that is nevertheless crucial to tolerably reconcile this solution with the imperatives of primacy, unity and effectiveness of EU law ${ }^{111}$. The national provisions on limitation at issue should still be applied despite the "Taricco interpretation of art. 325 TFEU" only to persons accused of committing VAT infringements before the delivery of the Taricco I judgment. Only within this time frame are national courts not obliged to comply with the "Taricco obligation under art. 325 TFEU even if compliance with the obligation allowed a national situation incompatible with EU law to be remedied"112. But, after the delivery of the Taricco I judgment, the interpretation of art. 325 TFEU and its effects on national courts and individuals were made reasonably predictable. Therefore, the enfranchisement of national courts resulting from the Taricco II judgment ceases and the "Taricco obligation under art. 325 TFEU" stands, requiring national courts to disapply the national provisions on limitation at issue in criminal proceedings for infringements relating to VAT.

Additionally, the Taricco II judgment specifies that such enfranchisement of national courts does not extend to national legislature. As mentioned above, the burden of compliance with the 'Taricco interpretation of art. 325 TFEU' primarily lies with the national legislature. Therefore, the ECJ concludes, "[it] will then be for the national legislature to take the necessary measures" ${ }^{113}$. Calling the national legislature in a conundrum primarily designed by reference to national courts is not unprecedented in ECJ case-law ${ }^{114}$. The

110 Judgment of the Court in M.A.S. and M.B. (Taricco II), C-42/17, EU:C:2017:936, para. 57.

111 Considering that the ECJ introduced an (unprecedented) exception to the primacy of EU law, see Burchardt (2017); or that the ECJ followed a "constitutional tolerance" approach to primacy, see Bassini and Pollicino (2017b).

112 Judgment of the Court in M.A.S. and M.B. (Taricco II), C-42/17, EU:C:2017:936, para. 61.

113 Judgment of the Court in M.A.S. and M.B. (Taricco II), C-42/17, EU:C:2017:936, para. 61.

114 See, for example, the judgment of the Court in Köbler, C-224/01, EU:C:2003:513, para. 125 . 
national legislature remains under an obligation of toilettage (Rigaux, 1996: 4 ) in order to ensure the primacy, unity and effectiveness of EU law. The ECJ thus managed to fulfill the expectation created between the two Taricco judgments (Silveira and Perez Fernandes, 2017b), attempting a conciliatory solution without souring relations with national constitutional (and supreme) courts of the Member States.

\section{CONCLUDING REMARKS}

Inscribed at the heart of EU constitutional crossroads, protection of fundamental rights within the EU legal system is to be considered a good problem-a good problem being, not one that is resolved quickly (whether in a good or bad way), but one that transforms those who devotes themselves to it in the quest for solutions. And this is so because it continually places those who are devoted to it outside their respective comfort zones-for only there is it possible to move forward.

Within the internormative, comprehensive and constantly evolving system of fundamental rights protection progressively built within the EU legal system and now coded in the CFREU, balance between the structure and the objectives of the European integration process and the protection of fundamental rights is neither easy nor uncontroversial. Thus, even after the entry into force of the CFREU in 2010 and then with the case-law established in Fransson and Melloni since 2013, the protection of fundamental rights in the EU has known some incidents and moments of uncertainty and will continue to be written to the rhythm of advances and setbacks. Overall, the evolution has been rather positive. And, despite a somewhat laconic reasoning, the judgment in Taricco II fits this trend. The ECJ sought to articulate a compromise and pragmatic solution that, duly contextualized, provides an example of reflexive interaction of legal orders in solving common problems of fundamental rights (common constitutional problems) and the ongoing judicial dialogue that supports, promotes and enforces it.

Theorizing the constitutionalism model emerging from the European integration process, particularly in the field of fundamental rights protection, should accommodate a friendly approach to the interaction of different legal orders that avoids the occurrence of (artificial) constitutional conflicts when dealing with matters that affect all involved (Poiares Maduro, 2006: 38-47) and, in particular, promotes methodological solutions providing for a high standard of protection of fundamental rights. An integrative approach of intercomplementarity should be (legally and institutionally) encouraged rather than a hierarchical approach to conflict. The compromise solution reached in 
Taricco II regarding the principle of legality in criminal matters is an example of such approach valuing a common constitutional framework that integrates the difference at the expense of fragmentary constitutional identity claims.

The Taricco saga also demonstrates how, in the current moment of EU constitutionalism, national legal orders have lost their condition of "primary legal systems" without the EU legal order having yet acquired it; and how difficulties do not emerge from the existence of conflicts, but rather from the lack of "cross-cutting rules, techniques and mechanisms that may overcome those conflicts in a satisfactory fashion for both parties" (Balaguer Callejón, 2017: 11-12). In light of the Taricco II judgment, this reasoning may also apply to the legal chessboard of the European integration process concerning balance between its structure and objectives and the protection of fundamental rights. At the end, primacy, unity and effectiveness of EU law, imperatives that structure the relations between EU and national legal orders for the pursuit of the objectives of the European integration process, have given up their first place without the protection of fundamental rights having yet taken the lead alone-both sides of the balance partially yielded in the articulation of such a compromise solution without destroying or blocking each other in a global context.

Additionaly, the complex legal problems inherent to such plural, inclusive and dynamic system are only manageable through dialogue ${ }^{115}$ and cooperation. Within the constitutional model emerging from the European integration process, the legal orders of the EU and of the Member States cannot ignore each other and unilaterally decide on issues affecting all, especially where such issues are of a fundamental nature such as the protection of fundamental rights. If anything, the Taricco saga is of such a prime example, illustrating how an exercise of judicial diplomacy developed around a "stick and carrot strategy" can be elegantly put into use (Sarmiento, 2017) in order to turn moments of tension into moments of protection.

\section{Bibliography}

Balaguer Callejón, F. (2017). The dialectic relation between the national and the European constitutional identity in the framework of European Constitu-

115 Suggesting the emergence of a "dialogical Rule of Law" within the EU, but also offering a critical analysis of the ECJ's role in view of recent developments, including in Taricco, see Kochenov and van Wolferen (2018). 
tional Law. UNIO. EU Law Jounal, 3 (3), 10-24. Available at: https://doi. org/10.21814/unio.3.1.4.

Bassini, M. and Pollicino. O. (2017a). The Taricco Decision: A Last Attempt to Avoid a Clash between EU Law and the Italian Constitution. Verfassungsblog [blog], 281-2017. Avaliable at: verfassungsblog.de.

_ (2017b). Defusing the Taricco Bomb through Fostering Constitutional Tolerance: All Roads Lead to Rome. Verfassungsblog [blog], 5-12-2017. Avaliable at: verfassungsblog.de.

Bellamy, R. and Kröger, S. (2017). A demoicratic justification of differentiated integration in a heterogeneous EU. Journal of European integration, 39 (5), 625639. Available at: https://doi.org/10.1080/07036337.2017.1332058.

Besselink, L. (2007). A Composite European Constitution. Groningen: Europa Law Publishing.

- (2012). General Report. In J. Laffranque (ed.). The Protection of Fundamental Rights post-Lisbon. The interaction between the EU Charter of Fundamental Rights, the European Convention on Human Rights and National Constitutions. Reports of the FIDE Congress Tallinn 2012, Volume I. Tallinn: Tartu University Press.

— (2013). Multiple Political Identities: Revisiting the 'Maximum Standard'. In A. Silveira, M. Canotilho and P. Madeira Froufe (eds.). Citizenship and Solidarity in the European Union: from the Charter of Fundamental Rights to the Crisis, the state of the art. Brussels; New York: Peter Lang.

Braibant, G. (2001). La Charte des droits fondamentaux de l'Union européenne. Paris: Éditions du Seuil.

Budinska, B. and Vikarska, Z. (2017). Judicial dialogue after Taricco II: who has the last word, in the end? EU Law Analysis [blog], 7-12-2017. Avaliable at: eulawanalysis.blogspot.com.

Burchardt, D. (2017). Belittling the Primacy of EU Law in Taricco II. Verfassungsblog [blog], 7-12-2017. Avaliable at: verfassungsblog.de.

Canotilho, M. (2013). Artigo 53.․ Nível de proteção. In A. Silveira and M. Canotilho (coords.). Carta dos Direitos Fundamentais da União Europeia Comentada (pp. 606-624). Coimbra: Almedina.

De Búrca, G. (2001). The drafting of the European Union Charter of Fundamental Rights. European Law Review, 26 (2), 126-138.

De Witte, B. (2014). Article 53. S. Peers et al. (eds.). The EU Charter of Fundamental Rights. A Commentary (pp. 1523-1538). Oxford: Hart Publishing.

Duarte, M. L. (2006). União Europeia e Direitos Fundamentais no espaço da internormatividade. Lisbon: AAFDL. (2010). Estudos sobre o Tratado de Lisboa. Coimbra: Almedina.

Dutheil de la Rochère, J. (2010). Droits fondamentaux: quelle place dans l'architecture de l'Union. In Chemins d'Europe: mélanges en l'honneur de Jean Paul Jacqué (pp. 263-278). Paris: Dalloz. 
Eeckhout, P. (2002). The EU Charter of Fundamental Rights and the Federal Question. Common Market Law Review, 39 (5), 945-994. Available at: https://doi. org/10.1023/A:1020832600674.

Egger, A. (2006). EU-Fundamental Rights in the National Legal Order: The Obligations of Member States Revisited. Yearbook of European Law, 25 (1), 515-553. Available at: https://doi.org/10.1093/yel/25.1.515.

European Commission. (2009). Communication on the legal nature of the Charter of fundamental rights of the European Union, COM(2000) 559 final, 13-92000 .

European Council (1999). Decision on the drawing up of a Charter of Fundamental Rights of the European Union, Annex IV of the Conclusions of the Presidency of the Cologne European Council.

European Parliament (1989). Resolution adopting the Declaration of fundamental rights and freedoms, OJ C 120, 16-5-1989, 51-57.

Freixes, T. (2012). Quelles valeurs à protéger dans le dialogue interculturel euro méditerranéen? In T. Freixes et al.. La gouvernance multi-level. Penser l'enchevêtrement (pp. 109-141). Brussels: E.M.E..

García de Enterría, E. (dir.) and Alonso García, R. (subdir.). (2002). La Encrucijada Constitucional de la Unión Europea. Madrid: Civitas Ediciones.

Gomes Canotilho, J. J. (2006). Brancosos e Interconstitucionalidade. Itinerários dos discursos sobre a historicidade constitucional. Coimbra: Almedina.

— (2010). Estado de Direito e internormatividade. In A. Silveira (coord.). Direito da Uniāo Europeia e Transnacionalidade (pp. 171-185). Lisbon: Quid Iuris.

Hofmann, H. C. H. and Mihaescu, B. C. (2013). The Relation between the Charter's Fundamental Rights and the Unwritten General Principles of EU Law: Good Administration as the Test Case. European Constitutional Law Review, 9 (1), 73-101. Avaliable at: https://doi.org/10.1017/S1574019612001046.

Iglesias Sánchez, S. (2012). The Court and the Charter: the impact of the entry into force of the Lisbon Treaty on the ECJ's approach to fundamental rights. Common Market Law Review, 49 (5), 1565-1611.

Kaila, H. (2012). The Scope of Application of the Charter of Fundamental Rights of the European Union in the Member States. In P. Cardonnel, A. Rosas and N. Wahl (eds.). Constitutionalising the EU Judicial System: Essays in Honour of Pernilla Lindh (pp. 291-315). Oxford: Hart Publishing.

Kochenov, D. and van Wolferen, M. (2018). Dialogical Rule of Law and the Breakdown of Dialogue in the EU. EUI Department of Law Research Paper No. 2018/01. Avaliable at: https://ssrn.com/abstract=3104282.

Krajewski, M. (2017). "Conditional” Primacy of EU Law and its Deliberative Value: An Imperfect Illustration From Taricco II. European Law Blog [blog], 18-122017. Avaliable at: europeanlawblog.eu.

Ladenburger, C. (2012). Institutional Report. In J. Laffranque (ed.). The Protection of Fundamental Rights post-Lisbon. The interaction between the EU Charter of Fundamental Rights, the European Convention on Human Rights and National 
Constitutions. Reports of the FIDE Congress Tallinn 2012, Volume I. Tallinn: Tartu University Press.

Lenaerts, K. and Gutiérrez-Fons, J. A. (2014). The Place of the Charter in the EU Constitutional Edifice. In Peers et al. (eds.). The EU Charter of Fundamental Rights. A Commentary (pp. 1600-1637). Oxford: Hart Publishing. Available at: https://doi.org/10.5771/9783845259055_1600.

Lucas Pires, F. (1997). Introdução ao Direito Constitucional Europeu (Seu Sentido, Problemas e Limites). Coimbra: Almedina.

Perez Fernandes, S. (2013). O Tribunal de Justiça e o respeito pela identidade (constitucional) nacional dos Estados-Membros. In J. Freitas da Rocha (coord.). Anuário Publicista da Escola de Direito da Universidade do Minho. Tomo II, Ano de 2013. Ética e Direito (pp. 137-168). Braga: Departamento de Ciências Jurídicas Públicas da Escola de Direito da Universidade do Minho. Avaliable at: www.direito.uminho.pt.

— (2017). A proteção dos direitos fundamentais pelo direito da União Europeia: da Carta aos Estados, o enigma da Esfinge. CIEJD: Honorable Mention Jacques Delors Prize 2017. Available at: http://hdl.handle.net/1822/53241.

Pernice, I. (1999). Multilevel Constitutionalism and the Treaty of Amsterdam: European Constitution-Making Revisited? Common Market Law Review, 36 (4), 703-750. Available at: https://doi.org/10.1023/A:1018744426756. (2002). Multilevel Constitutionalism in the European Union. European Law Review, 27 (5), 511-529.

Platon, S. (2012). Le champ d'application des droits du citoyen européen après les arrêts Zambrano, McCarthy et Dereci. De la boîte de Pandore au labyrinthe du Minotaure. Revue trimestrielle de droit europeen, 48 (1), 23-52.

Poiares Maduro, M. (2006). A Constituição Plural. Constitucionalismo e Uniāo Europeia. Cascais: Principia.

Rangel, P. (2009). O Estado do Estado. Ensaios de politica constitucional sobre justiça e democracia. Dom Quixote.

Rigaux, A. (1996). L'arrêt Brasserie du Pêcheur-Factortame III: Le roi peut mal faire en droit communautaire. Europe, 6 (5), 1-6.

Ritleng, D. (2013). De l'articulation des systèmes de protection des droits fondamentaux dans l'Union. Les enseignements des arrêts Akerberg Fransson et Melloni. Revue trimestrielle de droit europeen, 49 (2), 267-292.

Rodríguez Portugués, M. (2016). Derechos fundamentales en la Unión Europea e interpretación constitucional. Revista Europea de Derechos Fundamentales, 28, 73-90.

Sarmiento, D. (2013). Who's afraid of the Charter? The Court of Justice, national courts and the new framework of fundamental rights protection in Europe. Common Market Law Review, 50 (5), 1267-1304.

- (2017). To bow at the rhythm of an Italian tune. Despite our Differences [blog], 5-12-2017. Avaliable at: despiteourdifferencesblog.wordpress.com.

Silveira, A. (2011a). Da interconstitucionalidade na União Europeia (ou do esbatimento de fronteiras entre ordens jurídicas. Scientia Ivridica, 326, 211-223. 
- (2011b). Principios de Direito da Uniāo Europeia. Doutrina e Jurisprudência, $2^{\text {nd }}$ ed. Lisbon: Quid Iuris.

— (2014). Do âmbito de aplicação da Carta dos Direitos Fundamentais da União Europeia: recai ou não recai? Eis a questão! Julgar, 22, 179-209.

— and Perez Fernandes, S. (2017a). A saga Taricco continua: entre identidade constitucional do Estado-Membro e nível mais elevado de proteção dos direitos fundamentais. Onde fica a efetividade do direito da União? Cadernos do Programa de Pós-Graduação em Direito, PPGDir./UFRGS, 12 (1), 5-27. Avaliable at: https://doi.org/10.22456/2317-8558.75956.

— and Perez Fernandes, S. (2017b). Taricco continues: Between constitutional national identity and highest level of protection of fundamental rights, where does effectiveness of EU law stand? The Official Blog of UNIO-EU Law Journal [blog], 21-7-2017. Avaliable at: officialblogofunio.com.

Tridimas, T. (2006). The General Principles of EU Law. Oxford: Oxford University Press.

Von Danwitz, T. and Paraschas, K. (2012). A fresh start for the Charter: Fundamental questions on the application of the European Charter of Fundamental Rights. Fordham International Law Journal, 35 (5), 1396-1426.

Ward, A. (2014). Article 51. S. Peers et al. (eds.). The EU Charter of Fundamental Rights. A Commentary (pp. 1413-1454). Oxford: Hart Publishing.

Weiler, J. H. H. and Fries, S. (1999). A Human Rights Policy for the European Community and Union: The Question of Competences. Harvard Jean Monnet Working Paper 4/99. Avaliable at: jeanmonnetprogram.org. 